\title{
PHYSICOCHEMICAL, CYTOTOXICITY AND GENOTOXICITY ASSESSMENT OF PALM OIL MILL EFFLUENT ON V79 CELLS
}

\author{
Awang, N. ${ }^{*}-$ Mustaffa, S. N. - MenG, C. K. \\ Environmental Health and Industrial Safety Programme, Faculty of Health Sciences, Universiti \\ Kebangsaan Malaysia, Jalan Raja Muda Abdul Aziz, 50300 Kuala Lumpur, Malaysia \\ *Corresponding author \\ e-mail: norm@ukm.edu.my
}

(Received $1^{\text {st }}$ Dec 2018; accepted $15^{\text {th }}$ Feb 2019)

\begin{abstract}
Palm oil mill effluent (POME) is the wastewater produced from palm oil refining activities like oil extraction, washing and cleaning processes in the mill that require an effective treatment before being discharged into waterways due to the effects it may have on the environment. The study was conducted in one of the mills that are located in Jerangau, Terengganu. This study was conducted to determine the physicochemical characteristics of POME on four different ponds which was mixing pond, facultative pond, algae pond and discharged pond. Discharged pond was the last pond for the POME treatment before it is discharged into the nearby river. The physicochemical parameters that have been determined to evaluate POME were $\mathrm{pH}$, temperature, BOD, COD and TSS. The physicochemical characterization was carried out to determine the profile of POME at that time and the results showed that all parameters exceed the standards set by the Regulations of the Environmental Quality (Industrial Effluent) Regulations 2009 Standard B of the Environmental Quality Act 1974 except the temperature. In addition, this study also aimed to determine and compare the effects of cytotoxicity and genotoxicity of POME between the four ponds towards V79 cells. The cytotoxicity can be determined using MTT assay to evaluate the cytotoxic effect of POME on V79 cells. Meanwhile the genotoxicity was determined by using the alkaline comet assay to evaluate the genotoxic effect of POME on V79 cells. The study found that the POME in all ponds showed the cytotoxic effects on V79 cells and the POME in discharged pond showed the highest $\mathrm{IC}_{50}$ value compared to the other ponds which was $75 \% \mathrm{v} / \mathrm{v}$. By using the $\mathrm{IC}_{25}$, the treatment towards V79 cells showed the value of the moments tail in the discharged pond was the lowest compared to the others which was $0.898 \pm 0.561$. The values of the tail moment are much lower when compared to the positive control which was $6.58 \pm 1.383$. Therefore, it can be concluded that the POME in a discharged pond had a lowest cytotoxic and genotoxic effects on V79 cells compared to other ponds. Keywords: genotoxicity, palm oil mill effluent, physicochemical characterizations, V79 cells
\end{abstract}

\section{Introduction}

Malaysia is the largest producer and exporter of palm oil. By 2010, Malaysia has contributed $41 \%$ of the world production for palm oil. While the palm oil industry has been recognized for its contribution towards economic growth and rapid development, it has also led to environmental pollution due to the production of large quantities of byproduct from the oil extraction process (Rupani et al., 2010). The waste products from palm oil processing consist of oil palm trunks (OPT), oil palm fronds (OPF), empty fruit bunches (EFB), palm pressed fibres (PPF) and palm kernel shells, less fibrous material such as palm kernel cake and liquid discharge palm oil mill effluent (POME) (Rupani et al., 2010; Sulaiman, 2010). Among the waste generated, POME is considered the most harmful waste for the environment if discharged untreated (Rupani et al., 2010). POME is a thick brownish liquid that contains high amounts of total solids $(40,500 \mathrm{mg} / \mathrm{L})$, oil and grease $(4000 \mathrm{mg} / \mathrm{L}), \mathrm{COD}(50,000 \mathrm{mg} / \mathrm{L})$ and BOD $(25,000 \mathrm{mg} / \mathrm{L})$. The disposal of this highly polluting effluent is becoming a major problem if it is not being treated 
properly besides a stringent standard limit imposed by The Malaysian Department of Environment for effluent discharged (Latif Ahmad et al., 2003).

The discharge of effluents without proper treatment to the environment will lead to the severe pollution and will affect to the people. POME contains fatty acids, protein, carbohydrates and other plant materials in a high volumes which is capable to change the parameters of the environment, especially BOD, DO and COD levels (Verla et al., 2014). In addition, the effluent also contains a colloidal suspension that affects the water such as a brown solid color, colloidal and oily (Latif Ahmad et al., 2003). It was identified as the major source of water pollution in Malaysia. If it is not treated before being discharge, this effluent would be a major problem to the environment (Lai et al., 2011).

This study discovers the cytotoxic and genotoxic effect of POME towards V79 cells that can be beneficial as safety alert to industries and community. Besides that, this study also comparing the cytotoxicity and genotoxicity effects between four ponds of POME at the mills. This research study has proven that there were cytotoxic effects and genotoxic effects that can be seen in the POME for four ponds. The in vitro cytotoxicity and genotoxicity study in this work will help the researchers to uncover the critical issue regarding the health risk associated with wastewater produced from palm oil refining activities and increase awareness among industrial practisers, thus leading towards more efficient and safe wastewater management.

\section{Materials and methods}

\section{Materials}

Chemicals used in this study were trypan blue solution, ethidium bromide (TBR), sodium hydrogen carbonate $\left(\mathrm{NaHCO}_{3}\right)$, hydrochloric acid $(\mathrm{HCl})$, sodium hydroxide $(\mathrm{NaOH})$, sodium chloride $(\mathrm{NaCl})$, disodium hydrogen phosphate $\left(\mathrm{Na}_{2} \mathrm{HPO}_{4}\right)$, triton $\mathrm{X}$ 100, distilled water, low melting agar (LMA) and normal melting agar (NMA). In addition, COD digestion reagent low range and high range for measuring COD from Hach Company (USA), powdered DMEM medium (supplemented with L-Glutamine and without sodium bicarbonate hydrogen) obtained from Gibco, US also used. Other chemicals were fetal bovine serum (FBS) obtained from JR Scientific USA, and penicillin/streptomycin from PAA (Germany). MTT tetrazolium salt from SigmaAldrich, USA and a dimethylsulfoxide (DMSO) solution from Fiesher Scientific, UK is also used in this study. Finally, the materials used are ethyl diamine disodium tetraacetate (Na2-EDTA), potassium chloride $(\mathrm{KCl})$ and potassium dihydrogen phosphate $\left(\mathrm{KH}_{2} \mathrm{PO}_{4}\right)$ from Ajax Chemical Laboratories, Unilab (NSW, Australia).

\section{Sampling location and time}

The study was conducted at one of the mills that are located at Terengganu. The mill produced the products such as crude palm oil (CPO) and kernel palm oil. The sampling was conducted on November, 2016. The samples were taken in the morning which was at $10 \mathrm{am}$ until $1 \mathrm{pm}$ and the samples taken was three times (triplicate) from each ponds which the effluents was collected. There are four ponds of effluent at the palm oil mill where all the product of filtration and purification will be stored in those ponds before being discharged into a nearby river. The four ponds were mixing pond, facultative pond, algae pond and discharged pond. 


\section{Physicochemical analysis}

The physicochemical properties that are being determined in this study were $\mathrm{pH}$ and temperature. The readings of these parameters were determined during the sampling because the readings are direct reading (in-situ). In addition, the reading of biochemical oxygen demand (BOD), chemical oxygen demand (COD) and total suspended solids (TSS) were also be determined. All the three readings of these parameters are analyzed ex-situ where the reading of this parameter evaluated in the laboratory using appropriate equipment.

\section{Cell line}

The cytotoxicity study was performed on V79 cell line, which is a type of lung fibroblast cells derived from Chinese hamster male, Cricetulus griseus. The cells were cultured in complete growth media Dulbecco's Modified Eagle's Medium (DMEM) enriched with $10 \%$ fetal bovine serum (FBS) and $1 \%$ penicillin/streptomysin.

\section{Cell viability assay}

The viability of V79 cells were determine using 3-(4, 5-dimethylthiazol-2-yl)-2, 5diphenyltetrazolium bromide (MTT) assay (Mossman, 1983). Cells were seeded in a sterile $96-w e l l$ microplate at density of $5 \times 104$ cells $/ \mathrm{mL}$ and incubated for $24 \mathrm{~h}$. Later, the medium in each well was discarded and replaced with a fresh medium containing tested samples at concentrations $100,50,25,12.5$ and $6.25 \%$ v/v. After $24 \mathrm{~h}$ treatment, $20 \mu \mathrm{L}$ of $5 \mathrm{mg} / \mathrm{mL}$ MTT solution was added to each well and incubated for $4 \mathrm{~h}$. An approximate of $180 \mu \mathrm{L}$ of media was removed and added with $180 \mu \mathrm{L}$ DMSO in each well. After $15 \mathrm{~min}$ incubated, the plate was agitated using orbital shaker to ensure the complete dissolve of the crystal formazan. The Optical Density (OD) of each well was measured at $570 \mathrm{~nm}$ wavelength using iMark Microplate Reader (BioRad, USA). The inhibitory concentration that induced cytotoxicity in $50 \%$ cell population $\left(\mathrm{IC}_{50}\right)$ was calculated and compared with the positive control. Menadione was used as positive control and untreated cells as a negative control.

\section{Alkaline comet assay}

The genotoxic effect of POME on V79 cells was assessed using comet assay, carried out under alkaline condition (Singh et al., 1988). The cells were seeded in 6-well plate at density of $5 \times 104$ cells $/ \mathrm{mL}$ and incubated for $24 \mathrm{~h}$. After $24 \mathrm{~h}$, the media was discarded from each well and replaced with a fresh media containing water sample treatment and incubated for next $24 \mathrm{~h}$. The procedure was performed in dark condition to avoid any interfering factors that can contribute to DNA damage such as direct radiation from the light. After that, the cells were harvest and pellet was collected. Then, the pellet was suspended in $3 \mathrm{~mL}$ PBS and then was aliquot $1 \mathrm{~mL}$ each into eppendorf tube. The tubes were then centrifuged at $2500 \mathrm{rpm}$ for $5 \mathrm{~min}$ at $4{ }^{\circ} \mathrm{C}$. The pellet was then washed with PBS and centrifuged again. Later, the pellet was collected and stored in cold condition.

Fully frosted slides were covered with $0.6 \%$ normal melting point (NMP) agarose. When this slide was solidified, a second layer containing the cells mixed with $0.6 \%$ low melting point (LMP) agarose was placed on the slide. After $5 \mathrm{~min}$ of solidification on ice, the slides were covered with $0.6 \%$ LMP agarose. They were then immersed for 1 to 
$24 \mathrm{~h}$ in $4{ }^{\circ} \mathrm{C}$ lysis solution. The slides were then placed on a horizontal gelelectrophoresis tank, facing the anode. The fresh electrophoretic buffer was filled into the tank in which the slides were put for 20 min to allow DNA unwinding and the expression of alkali-labile sites. Denaturation and electrophoresis were performed at $4{ }^{\circ} \mathrm{C}$ under dim light. Electrophoresis was carried out for $20 \mathrm{~min}$ at $25 \mathrm{~V}(300 \mathrm{~mA})$. Subsequently, the slides were rinsed gently three times with a neutralization buffer in order to remove excess alkali and detergents. Then, each slide was stained with $30 \mu \mathrm{L}$ ethidium bromide covered with a cover-slip. Fifty randomly selected cells were analyzed per sample. The slides were examined at $250 \times$ magnifications with a fluorescence microscope equipped with a 515-560 nm excitation filter and a $590 \mathrm{~nm}$ barrier filter, and images of cells were analyzed with the computerized image analysis system Comet Score III. The tail length was evaluated to quantify DNA damage.

\section{Statistical analysis}

All the investigated data were statistically analyzed using (SPSS). The comparisons between groups were done by one way analysis of variance (ANOVA). The level of statistical significance was set at $P$ value of $<0.05$.

\section{Results and discussion}

\section{Physicochemical analysis}

Table 1 showed the mean values \pm SEM (standard error mean) for each parameter ( $\mathrm{pH}$, temperature, BOD, COD and TSS) in different types of ponds. The Environmental Quality (Industrial Effluent) Regulations 2009 Standard B, Environmental Quality Act 1974 was used as a standard for comparison. The $\mathrm{pH}$ value obtained for effluent sample in mixing, facultative, algae and discharge ponds was $4.51 \pm 0.20,7.62 \pm 0.16$, $8.58 \pm 0.29$ and $8.91 \pm 0.12$ respectively. All the values were below the standard limit allowed by the Environmental Quality (Industrial Effluent) Regulations 2009 Standard B, the Environmental Quality Act 1974 ( $\mathrm{pH}$ 5.5- 9.0) except for effluent sample from mixing pond which has the acidic $\mathrm{pH}$. This might be due to the accumulation of raw POME in mixing pond as the effluent collected in mixing pond was directly from the mill. As the POME underwent biodegradation process along the way to the next ponds which were facultative, algae and discharge ponds, the effluent turned out to be basic and increase the $\mathrm{pH}$ in the respective ponds. Biodegradation occurred whereas the active microorganisms used up organic materials in POME as their nutrients and decomposed them into methane, carbon dioxide, hydrogen sulphide and water. According to Okwute and Nnennaya (2007), the $\mathrm{pH}$ of the raw POME released is acidic but after the biodegradation occurs, it gradually turns into alkali. This is because long-term POME retention in each pond causes biodegradation to occur where it depends on active microorganisms, which use organic ingredients in POME as nutrients and ultimately elaborate these organic substances in the form of simple products such as methane, carbon dioxide, Hydrogen sulfide and water (Okwute and Nnennaya, 2007; Jameel et al., 2011).

For the temperature, the average value obtained from the mixing pond, facultative pond, algae pond and the discharged pond were $32.80 \pm 0.61{ }^{\circ} \mathrm{C}, 30.00 \pm 0.20{ }^{\circ} \mathrm{C}$, $27.60 \pm 0.20{ }^{\circ} \mathrm{C}$ and $27.47 \pm 1.88{ }^{\circ} \mathrm{C}$, respectively. Based on the standards, the temperature obtained did not exceed the temperature permitted $\left(40^{\circ} \mathrm{C}\right)$. However, the 
temperature in mixing pond was slightly higher $\left(32.8^{\circ} \mathrm{C}\right)$ compared to another ponds. This is because mixing pond was the first pond introduced with effluent discharged from the mill which was normally in high temperature $\left(80-90{ }^{\circ} \mathrm{C}\right)$ (Khalid et al., 1992). Nevertheless, the temperature of the effluent decreased by time as heat released. In our study, the sampling was conducted after a certain period the effluent was released (the effluent released in the morning), and thus gave the lower monitored temperature compared to the temperature when effluent was first released. Besides, the temperature also dropped as the effluent flew to the next ponds and that was why we could observe the temperature in the each pond was lower compared to the pond before.

Table 1. Average value of $\mathrm{pH}$, temperature, BOD, COD and TSS for POME obtained in mixing ponds, facultative ponds, algae ponds and discharged ponds

\begin{tabular}{c|c|c|c|c|c}
\hline \multirow{2}{*}{ Ponds } & \multicolumn{5}{|c}{ Parameters } \\
\cline { 2 - 6 } & $\mathbf{p H}$ & Temperature $\left({ }^{\circ} \mathbf{C}\right)$ & $\mathbf{B O D}(\mathbf{m g} / \mathbf{L})$ & $\mathbf{C O D}(\mathbf{m g} / \mathbf{L})$ & TSS $(\mathbf{m g} / \mathbf{L})$ \\
\hline Mixing & $4.51 \pm 0.20$ & $32.80 \pm 0.61$ & $25600.00 \pm 300.00$ & $2241.33 \pm 18.95$ & $22524.00 \pm 2340.00$ \\
Facultative & $7.62 \pm 0.16$ & $30.00 \pm 0.20$ & $71.00 \pm 2.00$ & $338.67 \pm 7.02$ & $151.67 \pm 14.04$ \\
Algae & $8.58 \pm 0.29$ & $27.60 \pm 0.20$ & $35.00 \pm 2.65$ & $161.33 \pm 4.04$ & $45.67 \pm 4.16$ \\
Discharged & $8.91 \pm 0.12$ & $27.47 \pm 1.88$ & $25.00 \pm 3.61$ & $136.00 \pm 3.61$ & $34.33 \pm 4.16$ \\
\hline
\end{tabular}

In the other hand, the BOD and COD in mixing and facultative ponds were higher than standard limit. The value allowed for both BOD and COD were 50 and $200 \mathrm{mg} / \mathrm{L}$. The value for BOD and COD in mixing pond were $25600.00 \pm 300.00$ and $2241.33 \pm 18.95 \mathrm{mg} / \mathrm{L}$, while in the facultative pond the value for both were $71.00 \pm 2.00$ and $338.67 \pm 7.02 \mathrm{mg} / \mathrm{L}$. Meanwhile, BOD and COD content in algae and discharge ponds were still in allowed level.

Meanwhile, the TSS value for mixing and facultative ponds exceeded the standard limit $(100 \mathrm{mg} / \mathrm{L})$ compared to the other two ponds. The value for each pond was $22524.00 \pm 2340.00 \quad \mathrm{mg} / \mathrm{L}, \quad 151.67 \pm 14.04 \quad \mathrm{mg} / \mathrm{L}, \quad 45.67 \pm 4.16 \quad \mathrm{mg} / \mathrm{L} \quad$ and $34.33 \pm 4.16 \mathrm{mg} / \mathrm{L}$ respectively for each pond.

The results obtained for parameters of biochemical oxygen demand (BOD), chemical oxygen demand (COD) and total suspended solids (TSS) showed that the average value for those parameters of POME in the mixing pond was the highest than the others. The mixing pond normally contained the raw POME which was first released from the mill. Raw POME was a high pollution wastewater with high BOD and COD which can cause severe pollution to the environment that eventually polluted the water sources (Lam et al., 2011). Therefore, the values of BOD, COD and TSS in the mixing pond were higher compared to the other ponds. The BOD and COD values are important indicator to define the composition of wastewater and its effects towards the environment (Jameel et al., 2011). However, the content of BOD, COD and TSS decreased as the effluent distributed to the next ponds which were facultative, algae and discharged ponds, the value decreased. This was due to some processes that took place along the way the POME was released, such as a pre-treatment in the mixing pond, and biological treatments in the facultative and algae ponds. The pre-treatment was performed to reduce the suspended solids and oils by using flocculation, solvent extraction, adsorption and membrane separation processes (Latif et al., 2003). 
According to Wong (1980), the treatment system of POME usually consists of anaerobic and aerobic treatments. Aerobic treatment was required to reduce the concentration of BOD to produce effluents that comply with national effluent discharge standards (Salihu and Alam, 2012).

Based on the results of the study, all parameters such as $\mathrm{pH}, \mathrm{COD}, \mathrm{BOD}$ and TSS of POME in mixing pond were exceed the specified limits except for the temperature where the values are still in the range. Whereas the result obtained in the facultative pond for all parameters were above the prescribed standard except for $\mathrm{pH}$ and temperature. Meanwhile, for algae ponds and discharged pond, all parameters such as $\mathrm{pH}$, temperature, BOD, COD and TSS do not exceed the prescribed standards.

\section{Cytotoxicity of palm oil mill effluent sample on V79 cells}

Figures 1-4 showed a graph of cell viability against sample concentration from each tested pond. The viability of V79 cells exhibited a decrease in concentration-dependent manner for sample from each pond. Based on Figure 1, the percentage of cell viability was $106.73 \pm 0.025,103.20 \pm 0.026,82.58 \pm 0.05 \%, 57.88 \pm 0.067 \%$ and $6.46 \pm 0.03 \%$ at concentrations $6.25,12.5,25,50$ and $100 \% \mathrm{v} / \mathrm{v}$. The IC50 was obtained at concentration $58 \%$ v/v. Meanwhile, for facultative pond (Fig. 2), IC50 value was $61 \%$ $\mathrm{v} / \mathrm{v}$. The cell viability reduced from $79.8 \pm 0.018,76.06 \pm 0.028,64.21 \pm 0.029$ $59.32 \pm 0.032 \%$ and $8.84 \pm 0.01 \%$ for concentrations $6.25,12.5,25,50$ and $100 \% \mathrm{v} / \mathrm{v}$. Next, IC50 concentration for sample from algae pond (Fig. 3) was determined at 62\% $\mathrm{v} / \mathrm{v}$ with cell viability decreased from $99.4 \pm 0.043,101.77 \pm 0.022,80.52 \pm 0.014$, $60.84 \pm 0.024$ and $13.85 \pm 0.012 \%$ for concentrations as previous. For the discharged pond (Fig. 4), the graph also showed a slight increase in cell viability for concentrations $6.25,12$ and $5.25 \% \mathrm{v} / \mathrm{v}$ in which the viability was $94.8 \pm 0.011,107.33 \pm 0.063$, and $109.19 \pm 0.051$ respectively. However, the viability started to decrease to $83.02 \pm 0.018$ and $15.48 \pm 0.015 \%$ when treated with 50 and $100 \% \mathrm{v} / \mathrm{v}$ sample. The IC50 value obtained was $72 \% \mathrm{v} / \mathrm{v}$. Based on all the graphs displayed, we can observed that there were some points in the graphs where the cell viability at certain concentration was higher from the previous concentration and this might be due to adaptive response of the cells towards the certain concentration (Klassen and Eaton, 2001).

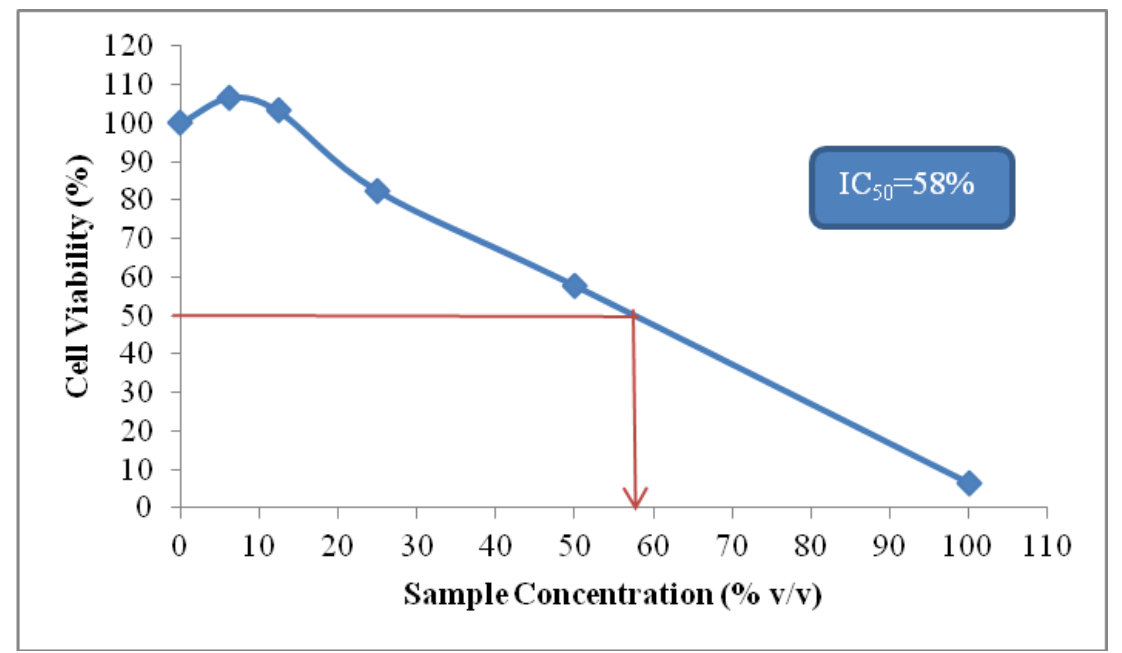

Figure 1. The viability of the V79 cell against the effluent sample concentration of the mixing pond after being treated for $24 \mathrm{~h}$ 


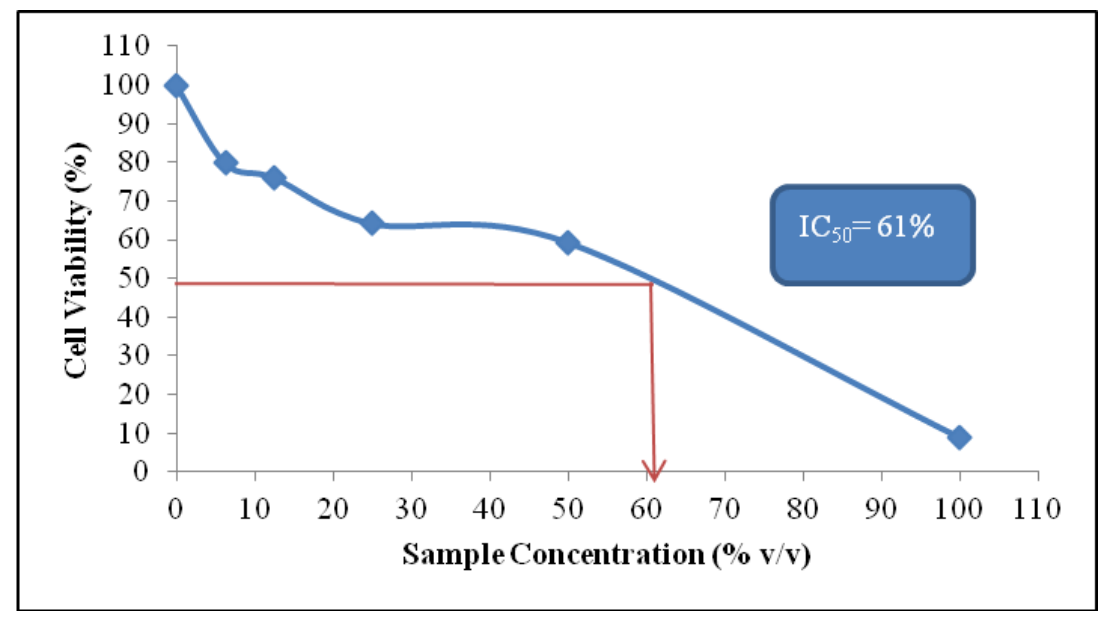

Figure 2. The viability of V79 cell against the concentration of effluent samples from the facultative pond after being treated for $24 \mathrm{~h}$

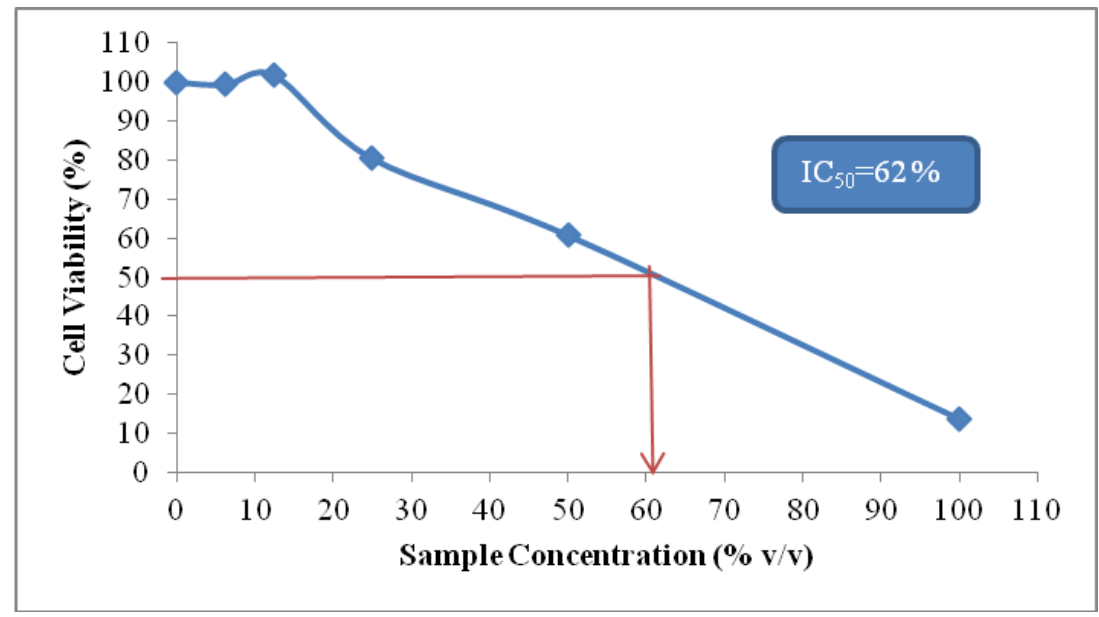

Figure 3. The viability of the V79 cell against the effluent sample concentration of the algae pond after being treated for $24 \mathrm{~h}$

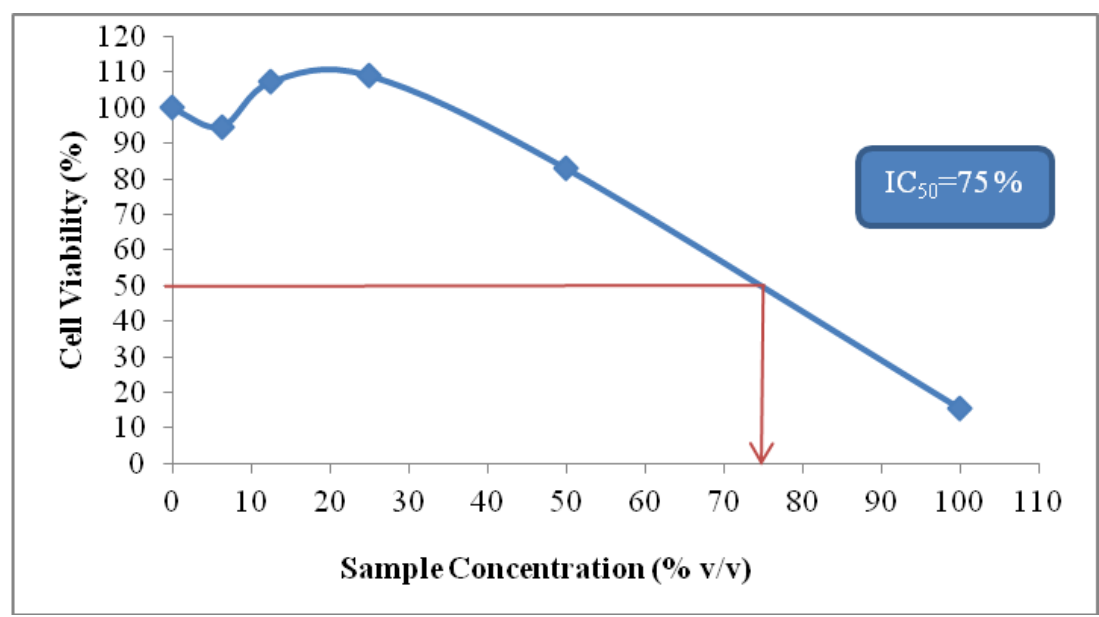

Figure 4. The viability of the V79 cell against the concentration of the effluent sample from the discharged pond after being treated for $24 \mathrm{~h}$ 
Based on the result obtained, the cytotoxicity of POME in the mixing pond was the highest than the others. The highly cytotoxicity of POME in mixing pond was caused by the content of oil and grease compounds present in the mixing pond where those compound can cause cytotoxic effects to POME. The highly oil and grease content is due to the production of POME directly from the mill without any treatment. The high content of oil and grease was proven by Latif Ahmad et al. (2003) where he stated that the raw sample consists of high oil and grease $(191 \mathrm{mg} / \mathrm{L})$. Furthermore, the production of raw POME is from the oil extraction, washing and cleaning process in the mill and it contained cellulose, fat, oil and grease (Rupani et al., 2010). In addition, oils and greases are considered dangerous pollutants especially in aquatic environments, since these compounds are highly toxic to aquatic organisms (Agamuthu, 1995).

On the other hand, the cytotoxicity of POME in discharged pond was the lowest compared to other ponds. The decrease of cytotoxicity in the discharged pond was due to the presence of biological treatments in the facultative pond and algae pond. POME in the discharged pond was the result from the treatment on those ponds. This biological treatment depends largely on active microorganisms, which use organic ingredients in POME as nutrients and ultimately degradation of these organic matter into simple products such as methane, carbon dioxide, hydrogen sulfide and water (Jameel et al., 2011). In addition, according to Azbar and Yonar (2004), wastewater treatment of palm oil refinery industry based on coagulation and biological methods caused in the overall removal of $92-96 \%$ COD, $83-98 \%$ TSS and $93-95 \%$ oil.

\section{Genotoxicity}

Comparison of DNA damages between mixing pond, facultative ponds, algae ponds and discharged pond

Figure 5 showed the tail moment of V79 cell treated with concentration IC25 of effluent sample from each pond together with menadione and untreated cells as positive and negative controls. The IC25 values was choose as the treatment concentration in order to avoid the highly damaged cells have gone into apoptosis and that the fragmented DNA disappeared from the gel, leaving only relatively undamaged cells.

Based on the bar graph, cells treated with POME from mixing pond gave tail moment $1.948 \pm 0.187$ while for the facultative pond the tail moment was $1.560 \pm 0.220$. Meanwhile, the tail moment value $1.234 \pm 0.204$ and $0.898 \pm 0.561$. was attributed for both algae and discharged ponds. On the other side, the tail moment values for positive and negative controls were $6.58 \pm 1.383$ and $0.328 \pm 0.200$, respectively. However, the genotoxic effecs of POME from all the four ponds was not significant when compared to negative control at $\mathrm{p}<0.05$.

Nevertheless, the genotoxic effect still could be detected in each pond as the tail moment was formed based on alkaline comet assay conducted. For example, POME sample from mixing pond induced the highest tail moment formation compared to other ponds. This might due to the presence of phenolic compounds in raw POME accumulated in mixing pond and suggested with finding by Jameel et al. (2011) that reported palm oil refineries contained some phenolic compounds such as Gallic, protocatechuic, 4-hydroxybenzoic, 4-hydroxylphenylacetic, caffeic, syringic acid, pcoumaric and ferulic acid. Based on $\mathrm{Li}$ et al. (2005), they found that phenol is a genotoxin evidence that can cause DNA damage. However, the biological treatments carried out as the effluent move to the next ponds eliminated those phenolic compounds 
(Hussain et al., 2015) and thus, decreased the toxicity of POME by ponds. That was why the tail moment observed in this study reduced by ponds.

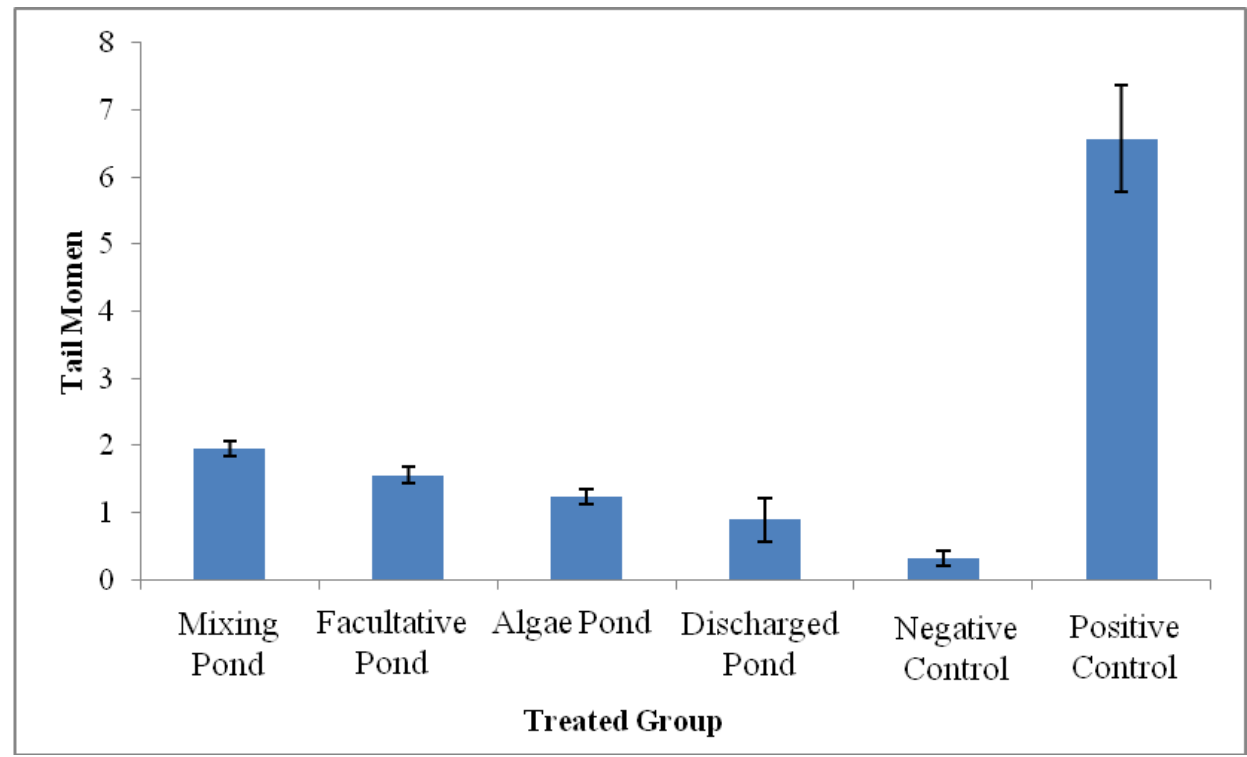

Figure 5. Comparison of the tail moment of V79 cell for negative control, positive control and effluent samples for each pond which were mixing pond, facultative pond, algae pond and discharged pond according to their respective concentration of $I C_{25}$

\section{Conclusion}

From this study, the physicochemical assessment of POME from the mixing and facultative ponds at the sampling location in Terengganu has exceeded the standard limit allowed by the Environmental Quality (Industrial Effluent) Regulations 2009 Standard B, Environmental Quality Act 1974. The other two ponds which were algae and discharged ponds were still under control. However, the MTT and alkaline comet assays conducted showed that POME sample from all ponds have cytotoxic and DNA damage effects towards V79 cells based on IC50 values and tail moments values obtained. Even though the treatment processes in each pond might be able to reduce the effects of POME before it was discarded into the nearby river, the long term effect of exposure of this wastewater is still under concern. Thus, a more efficient and proper management and treatment of wastewater in the sampling location are still required. For example is by performing a pre-treatment of POME wastewater using ultrafiltration membrane technique which coupled with absorption treatment (Azmi and Yunos, 2014). The ultrafiltration treatment coupled with adsorption treatment as pre-treatment is and advantageous method for the POME treatment. This treatment offer the easier operating conditions, more ability to combine with two technique and easier control of the system.

Acknowledgements. We would like to thank Palm oil mill at Jerangau, Terengganu for the cooperation given. Technical support from the laboratory assistants of Faculty of Health Sciences Universiti Kebangsaan Malaysia is gratefully acknowledged. 


\section{REFERENCES}

[1] Agamuthu, P. (1995): Palm Oil Mill Effluent Treatment and Utilization. - In: Sastry, C. A., Hashim, M. A., Agamuthu, P. (eds.) Waste Treatment Plant. Narosa Publishing House, New Delhi pp: 338-360.

[2] Azbar, N., Yonar, T. (2004): Comparative evaluation of a laboratory and full-scale treatment alternatives for the vegetable oil refining industry wastewater. - Process Biochemistry 39(7): 869-875.

[3] Azmi, N. S., Yunos, K. F. M. (2014): Wastewater treatment of palm oil mill effluent (POME) by ultrafiltration membrane separation technique coupled with adsorption treatment as pre-treatment. - Agriculture and Agricultural Science Procedia 2: 257-264.

[4] Hussain, A.,. Dubey, S. K., Kumar, V. (2015): Kinetic study for aerobic treatment of phenolic wastewater. - Water Resources and Industry 11: 81-90.

[5] Jameel, P.,. Idris, Z. M., Alam, M. Z. (2011): Effects of physicochemical parameters on the production of phenolic acids from palm oil mill effluent under liquid-state fermentation by Aspergillus niger. - Food Chemistry Journal 124: 1595-1602.

[6] Khalid, A. R., Mustafa, W. A. W. (1992): External benefits of environmental regulation: resource recovery and the utilisation of effluents. - The Environmentalist 12: 277-285.

[7] Klassen, C. D., Eaton, D. L. (2001): Casarett's and Doull's Toxicology: Principle of Toxicology. - McGraw Hill, New York.

[8] Lai, M. E., Lheang, L. S., Salimon, J. (2011): Effectiveness Of Palm Oil Sewage Treatment Using Zero Sewage Technology. - UKM Coolocium, Bangi.

[9] Lam, M. K., Lee, K. T. (2011): Renewable and sustainable bioenergies production from palm oil mill effluent (POME): Win-win strategies toward better environmental protection. - Biotechnology Advances 29: 124-141.

[10] Latif, A., Suzylawati, I., Norliza, I., Subhash, B. (2003): Removal of suspended solids and residual oil from palm oil mill effluent. - Journal of Chemical Technology and Biotechnology 78(9): 971-978.

[11] Latif Ahmad, A., Ismail, S., Bhatia, S. (2003): Water recycling from palm oil mill effluent (POME) using membrane technology. - Desalination 157(1): 87-95.

[12] Li, Y., Qu, M., Sun, L., Wu, Y., Chen, Y., Chen, H., Kong, Z and Liu, Z. (2005): Genotoxicity study of phenol and ocresol using the micronucleus test and the comet assay. - Toxicological \& Environmental Chemistry 87: 3365-372.

[13] Okwute, L. O., Nnennaya, I. R. (2007): The environmental impact of palm oil mill effluent (POME) on some physicochemical parameters and total aerobic bioload of soil at a dump site in Anyigba, Kogi State, Nigeria. - African Journal of Agricultural Research 2(12): 656-662.

[14] Rupani, P. F., Singh, R. P., Ibrahim, M. H., Esa, N. (2010): Review of current palm oil mill effluent (POME) treatment methods: vermicomposting as a sustainable practice. World Applied Sciences Journal 10(10): 1190-1201.

[15] Salihu, A., Alam, M. Z. (2012): Palm oil mill effluent: a waste or a raw material? Journal of Applied Sciences Research 8(1): 466-473.

[16] Singh, N. P., Mc Coy, M. T., Tice, R. R., Schneider, E. L. (1988): A simple technique for quantitation of low levels of DNA damage in individual cells. - Exp Cell Res 175: 184191.

[17] Sulaiman, A. (2010): Accelerated start-up of a semi-commercial digester tank treating palm oil mill effluent with sludge seeding for methane production. - World Appl. Sci. J 8(2): 247-258.

[18] Verla, A. W., Adowei, P., Verla, E. N. 2014): Physicochemical and microbiological characteristic of palm oil mill effluent (POME) in Nguru: Aboh Mbaise, Eastern Nigeria. - Acta Chimica \& Pharmaceutica Indica 4(3): 119-125.

[19] Wong, K. K. (1980): Application of ponding systems in the treatment of palm oil mill and rubber mill effluents. - Pertanika Journal 3(2): 133-141. 